\title{
João Cabral: \\ 70 anos; 50 de uma poética
}

\author{
Aguinaldo Gonçalves
}

Mascarada pelos desígnios da representação, nas mais variadas formas de amostragem, a obra poética de João Cabral de Melo Neto constitui um intrincado sistema de relações polissêmicas, amplo demais para ser sintetizado, complexo demais para que se tenha a pretensão de elucidá-lo. Nos cinqüenta anos dessa poesia, ao crítico compete dela valer-se como forma de reflexão sobre a natureza do poético e sobre a natureza de outros sistemas artísticos que se realizam a partir de procedimentos similares. Nesses cinqüenta anos, pode-se falar de um sistema poético de João Cabral, compacto, difuso e implosivo se se apreendem seus procedimentos que implicam verdadeiro estilhaçamento da linguagem. Esse fenômeno rompe com a dimensão meramente comunicativa da mensagem gerando, na sua dimensão expressiva, possibilidades variadas de semioses. Mediante essa ambiência construída, adentrar o sistema poético de João Cabral significa compartilhar de um verdadeiro teatro de signos. Esse universo se compõe de uma produção que se iniciou em 1941 com a publicação do livro Pedra do sono, que o poeta dedicou a Willy Lewin e a Carlos Drummond de Andrade. Como epígrafe ou como proa desta navegação, Cabral se valeu do verso "Solitude, récif, étoile", o primeiro do último terceto de "Salut" de Stéphane Mallarmé. Assim, o poeta recifense "sem medo ao jogo do mar alto", iniciava do alto o complexo composicional de seu trabalho. Esse trabalho, marcado por um estilo ímpar, possui uma peculiaridade que o distingue dentre os melhores da poesia ocidental. Trata-se do modo como essa poesia realiza, além de sua função expressiva, a sua função crítica; o modo como se integram no seu construtivismo a função estética e a função metalingüística. Dada a impossibilidade de apreender totalmente as relações desse sistema, é necessário e mais prudente que se recortem alguns fios de prumo, alguns fundamentos determinantes que elucidem, em parte, essa produção.

\section{A Máquina de Sentidos}

De início, é necessário registrar que a poesia de João Cabral atua, em relação à linguagem e em relação ao mundo dos seres e das coisas, como uma máquina. Máquina abstrata e inteligente, capaz de triturar, moer e transformar a condição do signo estigmatizado, "encoberto no objeto que o porta", além de encoberto pelos olhos sociais dos homens que enunciam, para transmitirem seus restritos universos pessoais. A máquina de João Cabral gera os signos da arte. Esse processo de trituração do mundo imediatizado na linguagem manifesta-se, evidentemente, em todos os seus poemas, adquirindo ângulos ou nuanças distintos, dependendo da fase do processo evolutivo de sua poesia. Isso se dá devido a uma base comum de seu estilo, ao qual subjaz uma concepção de mimesis que lhe confere o tom geral da obra. Textos, dentre tantos outros, como "Dentro da perda da memória", "Tecendo a manhã", "Dois P. S. a um poema", "Rios sem discurso", “A palo seco", "Psicologia da composição”, “Uma faca só lâmina”, são al-
AGUINALDO GONÇALVES é professor-assistente-doutor do Instituto de Biociência, Letras e Ciências Exatas da Universidade Estadual Paulista "Júlio de Mesquita Filho", campus de São José do Rio Preto. Pesquisador no campo de Artes Comparadas, é autor de Transição e permanência Miró/João Cabral: da tela ao texto (Editora lluminuras). 

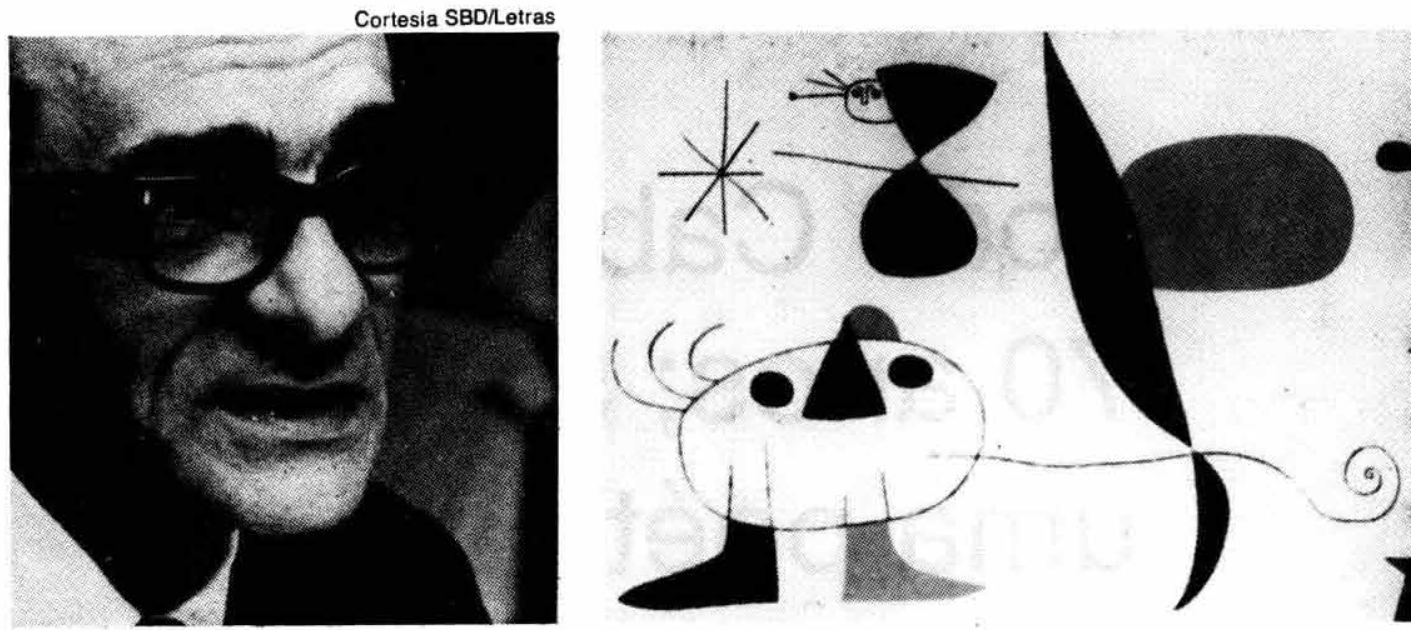

João Cabral; pintura mural, do catalão Joan Miró (coleção particular, Barcelona) guns dos que, além de apresentarem o funcionamento dessa máquina, demonstram o mecanismo de seu funcionamento. Sobretudo nesse tipo de texto, ocorre o que eu chamaria de reduplicação isotópica, isto é, fundida à metaforização dos sentidos do mundo vem a metaforização do funcionamento da linguagem. Aproximando um pouco mais a câmera desse fenômeno de construção cabralina, proponho a leitura do poema abaixo, contido na obra $A$ escola das facas:

\section{MOENDA DE USINA}

Clássica, a cana se renega ante a moenda (morte) da usina: nela, antes esbelta, linear, chega despenteada e sem rima. (Jogada às moendas dos banguês onde em feixes de estrofes ia, nāo protestava contra a morte, nem contra o que a morte seria). Na usina, ela cai de guindastes, anárquica, sem simetria: e até que as navalhas da moenda quebrando-a, afinal, a paginam, a cana é trovoada, troveja, perde a elegância, a antiga linha, estronda com sotaque gago de metralhadora, desvaria. Nāo fossem as saias de ferro da ante-moenda que a canalizam, quebrar-lhe os ossos baralhados faria explodir toda a usina. Nas moendas derradeiras tomba já mutilada, em ordem unida: não é mais cana multidāo que ao tombar é povo e não fila; ao matadouro final chega em pelotão que se fuzila.

Recuperando sempre a tradição, ou presentificando-a como ponto de partida no interstício da linguagem - "Clássica, a cana se renega" - o poema alegoriza a moenda, o poema, ou as questōes sociais proporcionadas por uma sociedade de classes. Seja a nível macroestrutural, ou a nível discursivo da microestrutura, os signos bailam, plasmando um ritmo, materializando a potência dos sentidos, latentes, mas sugeridos por todos os índices expressivos manifestados em todas as camadas lingǘrsticas utilizadas. A matéria-prima do texto (cana, poema ou povo) se confunde entre coisas e signos (açúcar
Setembro

Outubro

Novembro 


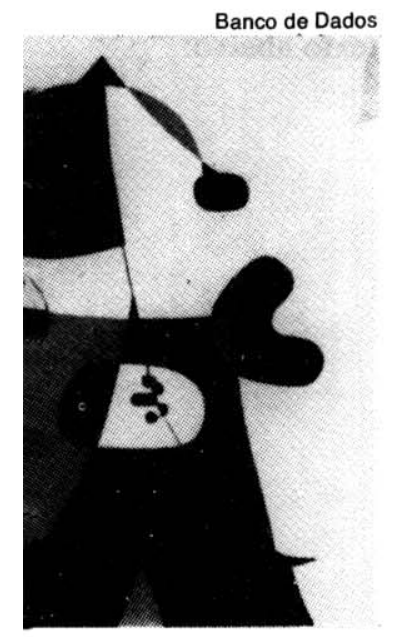

Partindo das concepções de Wolfgang

Iser a respeito da recepção do texto

literário, diria que, na interação entre

a poesia de João Cabral e o leiłor,

torna-se evidente que a atividade tem

de ser comandada pelo texto.

A própria forma de construção

não permite uma ilusão de fluência

tão comum nas leituras de poesia

ou poesia; tradição ou modernidade; movimento entre modernidade e tradição). Nessa mobilidade semântica, "Moenda de usina" prima por conseguir conjugar cruzamentos isotópicos, arquitetonicamente articulados. $O$ processo de semantização do texto se realiza dentro do que Julia Kristeva denomina "significância" - o texto se dá enquanto espaço produtor de sentidos. No confronto entre duas moendas emerge o poema, figurativizando nas imagens os planos de sentido e atingindo o ponto alto da poesia moderna: o plano de iconização.

Marcado no descompasso simétrico composto de decassílabos, octossílabos e eneassílabos, o bloco estrófico de 26 versos desenha as próprias engrenagens, enquanto no interior da moenda poética os signos e suas normas de organização sintática são triturados e "trovejam", através de uma confluência de oclusivas surdas e sonoras que se amontoam, mas se organizam graças às "saias de ferro" do poema. As "saias de ferro" representam o próprio rigor construtivo da poesia moderna e, em especial, de João Cabral, a ante-sala da grande entrada que alia, aos sentimentos do mundo, a consciência da racionalidade necessária para ir além dos "feixes de estrofes" das "moendas de banguês"'.

\section{O POEma Como Construto}

De máquina construtora, o poema passa, uma vez construído, à máquina disponível ao fornecimento de sentidos. Seus sentidos latentes entram em "sintonia possível" com o leitor. Novo processo, agora decisivo, se inicia. Uma vez paginado, posto em livro, posto nas bancas ou nas estantes, o poema lateja, em silêncio aparente, sua fome de diálogo ou de confronto, sua fome de transitar concretamente na esfera dos homens. Esse rio difícil de engrenagens de risco, escondidas na aparente correnteza, ganhará existência concreta na sua interação com o interlocutor. Este é o segundo componente que julgo fundamental para a leitura da poesia de João Cabral: sua consciência de que o poema é um construto imagético pleno de vazios que possibilitam a transitividade com o interlocutor. Lendo sua poesia e atentando para os recursos estilísticos que singularizam as camadas lingüísticas (léxico, sintaxe, entonação e sonoridade), nota-se que o poeta prevê e propõe ao leitor, de início, o estranhamento da linguagem; depois, a mobilidade de sentidos que vão emergindo na camada de superfície do texto.

Partindo das concepções de Wolfgang Iser a respeito da recepção do texto literário, eu diria que, na interação entre a poesia de João Cabral e o leitor, torna-se evidente que a atividade tem de ser comandada pelo texto. A própria forma de construção, sobretudo a sintática, não permite uma ilusão de fluência tão comum nas leituras de poesia. A maioria dos poemas impōe-se ao leitor, como um espaço de linguagem capaz de propiciar movimentos de sentido, desde que ele, o leitor, busque do lado interno da moldura as relações a serem estabelecidas. Assim, evidencia-se nessa forma de poesia o que é próprio do discurso poético, isto é, o movimento tem de ser centrípeto, mediante o modo peculiar da articulação da segunda língua, ou da semiótica conotativa. Essa esfera de relações se constrói por recortes e remontagens que atuam nas duas articulações da linguagem e é nessa órbita que deve penetrar o leitor. 
Como amostragem desse fenômeno artístico, proponho a leitura do texto abaixo:

\section{OS VAZIOS DO HOMEM}

Os vazios do homem não sentem ao nada

do vazio qualquer: do do casaco vazio, do da saca vazia (que não ficam de pé quando vazios, ou o homem com vazios); os vazios do homem sentem a um cheio de uma coisa que inchasse já inchada; ou ao que deve sentir, quando cheia, uma saca: todavia não, qualquer saca. Os vazios do homem, esse vazio cheio, não sentem ao que uma saca de tijolos, uma saca de rebites; nem têm o pulso que bate numa de sementes, de ovos.

\section{2.}

Os vazios do homem, ainda que sintam a uma plenitude (gora mas presença) contêm nadas, contêm apenas vazios: o que a esponja, vazia quando plena; incham do que a esponja, de ar vazio, e dela copiam certamente a estrutura: toda em grutas ou em gotas de vazio, postas em cachos de bolha, de não-uva. Esse cheio vazio sente ao que uma saca mas cheia de esponjas cheias de vazio; os vazios do homem ou o vazio inchado: ou o vazio que inchou por estar vazio.

Trigésimo-oitavo poema da estrutura quadrangular de $A$ educação pela pedra, esse texto se oferece ao leitor com uma face sedutora, atraente pelo assunto e por sua aparente explicitação referencial. "Os vazios do homem", tema genérico num livro em que os motivos temáticos são extraídos das duas vertentes básicas da obra: Pernambuco e Espanha. O título pluralizado acentua a dimensão lúdica do poema, que se propõe a driblar suas possíveis relações com o leitor e que se estende numa justaposição de imagens que se integram e se dissociam num movimento semântico ininterrupto e pluridirecionado. As imagens se interpenetram e são vários os focos de sentido que se projetam em profusão no leitor, mediante a sua construção que se dá à base de exaustão retórica. Num processo de composição que mimetiza o andamento da prosa em termos de macroestrutura, a nível microestrutural realiza a própria apologia do poético. Como discute Iuri Lotman em A estrutura do texto artistico, a noção metafísica de "processo" é substituída por uma noção dialética: "O elemento estrutural e sua função. A idéia de uma fronteira do verso e da prosa começa a ligar-se não só à realização no texto destes ou daqueles elementos da sua estrutura, mas à sua ausência significativa". "Os vazios do homem" é um excelente exemplo de ocorrência de tal fenômeno. Travestido por excessiva presença de imagens simbolizadoras do vazio, o poema "finge" esconder as ausências embora estejam nelas a denúncia dos pontos-chave para as significações do texto. Ocorre, assim, o processo homólogo à antimatéria da física molecular. Desse modo, o leitor que tenta desvendar a evolução semântica das imagens, em busca da compreensão dos "vazios", perde-se nos núcleos sêmicos, perde-se no redemoinho.

Portanto, o primeiro passo para a apreensão das relações básicas do texto se dá quando o leitor, ao sair da tentativa de compreender a linearidade sintagmática do discurso, percebe nas interrupçōes paradigmáticas a significação das ausências. Algumas ocorrências presentes no texto (dezenove vezes o signo "vazio" é atualizado) se contrapōem a outras ocorrências de ausências (outras tantas vezes o mesmo signo é sugerido por elipse). À hipérbole recorrente se unem outros índices significativos: algumas incongruências sintáticas - "não sentem ao nada" - são reiteradas no poema. Esses e outros aspectos vão conferindo ao discurso poético certa atmosfera de nonsense que 
acaba por desviar o leitor daquela ilusória referencialidade a que aludi no início desse trabalho. A lógica da semantização é questionada no próprio espaço da criação e o leitor percebe que esse fenômeno de sentido já estava evidente desde o primeiro verso, mas ocultado por certa "naturalidade sintática", agora desvendada. Ao invés de o sujeito do processo ser o homem - o homem sente o vazio ou o vazio sentido pelo homem -, nos 24 versos, é o vazio: "os vazios do homem não sentem ao nada": o sentimento de vazio torna-se sujeito do ato de sentir o sentimento de vazio. Como resultado, o poema se esvazia. O poema sente a um cheio de uma coisa que inchasse já inchada. $O$ poema é goro, mas presença. O poema é uma apologia ao signo poético. Valendo-se, portanto, de um procedimento paródico à retórica, o poema nos conduz ao silêncio, ao vazio. A excessiva figurativização do signo "vazios" (primeira palavra do poema) conduz ao esvaziamento do ser, através do signo "vazio" (última palavra do poema), conseguindo construir a iconização do abstrato.

Assim sendo, o poema se constrói pela ausência, pelo espaço ausente, pela inutilidade. O poema é inútil e pela inutilidade faz emergir a consciência. Da hipérbole ele mimetiza a estrutura da esponja cheia de vazios. Da pluralidade à singularidade: vazios $\mathrm{x}$ vazio, o poema aponta com o dedo em digonal a apreensão do que não se pode decifrar.

Esse texto é uma das mais claras demonstrações (dentro de seu obscurantismo) da poesia como construto intencional determinado por vazios. Ao chegarmos ao esvaziamento retórico, percebemos que a natureza ausente do poema chegou a ser inclusive mimetizada no "gesto" de gagueira do segundo e do terceiro verso: "do do casaco vazio", "do da saca vazia", corroborando a plasmação metalingüística do próprio processo de interação entre o texto artístico e o receptor.

\section{POESIA COMO ESPAÇO INTERSEMIótico}

O terceiro componente que vale como determinante na poesia de João Cabral é sua dimensão intersemiótica. A modernidade de sua obra faz jus ao fenômeno que se iniciou na segunda metade do século XIX e se propagou no século XX. Resultante da busca efetiva de sua própria natureza, cada sistema artístico passou a perscrutar, cada vez mais, o seu meio de expressão específico como elemento determinante, enformador e modificador dos processos de criação. Isso conferiu certo distanciamento entre as várias artes que buscavam nas suas proprias linguagens, sua autonomia. Paradoxalmente, cada arte passou a conviver com as artes vizinhas, tentando compreender seus procedimentos específicos e aqueles que poderiam ser utilizados por seu ofício, para ampliar sua potencialidade expressiva. A poesia de João Cabral é um exemplo efetivo desse fenômeno estético-semiótico. Basta que se leia um de seus livros, Poesia crítica, de 1982, para que se comprove isso. Trata-se de uma antologia organizada pelo próprio poeta e dividida em duas partes: I Linguagem; II Linguagens. Nessa obra, Cabral reúne poemas em que tomou como assunto a criação poética e o ato de criar ou personalidade de criadores poetas ou não. Para o próprio poeta, não se trata de "reiteração de verdades a que o autor teria chegado, mas apenas a conseqüência de uma permanente meditação sobre o ofício de criar". Consciente de que não pertence à família espiritual para quem a criação é um dom, o poeta justifica na "Nota do autor" o fato de continuar se interrogando e discutindo consigo mesmo a validade da criação poética. Essa validade, para ele, não se concentra na compreensão da linguagem poética como uma coisa autônoma, intransitiva, "uma fogueira ardendo por si", mas uma forma de linguagem como qualquer outra. Daŕ sua concepção de poesia como linguagem transitiva, desde que se preserve sua qualidade de linguagem poética. Ainda para João Cabral, podendo com a poesia falar de qualquer coisa, mais ainda é válida a sua natureza crítica, em que o próprio processo de criação se torna seu assunto. Se à poesia compete, aos olhos normais do crítico, tratar de objetos e seres da natureza, "por que - diz o poeta - não lhe caberia o mesmo direito diante de objetos que não se poderia catalogar como diretamente da natureza?". Esses objetos são as obras de arte (verbais, icônicos ou indiciais) que servem ao poeta como matéria-prima e que justificam a ampliação de seu trabalho com a palavra, através do trabalho de outros artistas com seus meios de construção. Desta forma, no que diz respeito à intersemioticidade e à resultante crítica e autocrítica desse fenômeno, João Cabral de Melo Neto representa um dos exemplos mais contundentes da literatura ocidental moderna. Essa avaliação, eu a faço, tendo na mira poetas estrangeiros como Mallarme, Eliot, Pound, Ungaretti, Valéry, e. e. cummings, Octavio Paz ou brasileiros como Murilo Mendes, Manuel Bandeira, Drummond e Augusto de Campos. Se cada um 
deles manifestou ou manifesta na sua obra a consciência crítica do of́́cio de criar, é na poesia de João Cabral que consigo perceber, da forma mais acentuada, uma convocação do crítico para o espaço do poema, enquanto realização intersemiótica. Na sua poesia, outros sistemas emergem direta ou indiretamente.

Alguns textos compõem perfeito fusionismo entre elementos da natureza e elementos do discurso. Em "O mar e o canavial", "O canavial e o mar", "A pedra do reino", por exemplo, em que ocorre uma inversão: as coisas são postas na condição de linguagem a linguagem das coisas. As coisas do mundo são atualizadas em dimensão sintagmática. Essa forma de construção - mundo/texto - não só desautomatiza o mundo das coisas, feito signos, como singulariza a linguagem, feito coisas.

Em outros casos, os poemas intensificam outro tipo de fusionismo: sua capacidade de fazer ver - poesia do olho - que, por procedimentos sinestésicos muito próprios, se articula à sua capacidade de fazer sentir. Sua poesia consegue "ler" pintura e transmudar o mundo das sensações em signos e os signos em sensorialidade espessa. É o que se pode ver, por exemplo, em "Homenagem a Picasso", "A Carlos Pena Filho", "A André Masson", e outros.

O diâmetro intersemiótico dẹssa poesia é amplo e abarca quase todos os sistemas de signos. Daí reconhecermos nela certo "isomorfismo", isto é, identidade formal da estrutura do sistema poético com outros sistemas que se estendem do arquitetônico (penso nas profundas influências de Le Corbusier) ao gestual (penso, sobretudo, nas bailadoras espanholas).

Por razões de predileção estética foi a relação entre a poesia de João Cabral e o código plástico (pintura e escultura) que me envolveu num sentido mais apurado durante os últimos anos e me levou a perceber o que passei a denominar de "homologia estrutural" entre poesia e pintura e mesmo entre poesia e escultura. Esse tipo de relação entre sistemas vai além das analogias e toma pela raiz as semelhanças possíveis de procedimentos que geram efeitos próprios devido ao meio de construção.

Com base no princípio retórico, em que a metáfora é considerada núcleo dos procedimentos do trabalho de arte, pude descrever, em parte, as íntimas relaçōes entre a poesia de João Cabral e a pintura de Joan Miró * . Entretanto, a relação homológica dessa poesia com as artes plásticas vai mais longe e se torna um riquíssimo campo para os pesquisadores de estética comparada. Deve-se atentar, por exemplo, para as aproximações de concepção sobre arte de João Cabral e de Piet Mondrian, ou de João Cabral e de alguns escultores. Atentar significa, aqui, ler atentamente essa poesia nos seus múltiplos movimentos de linguagem que implicam múltiplos movimentos de sentido e o mesmo fazer com a arte plástica de um Mondrian, respeitando a evolução de seu projeto plástico. Além desse empenho de leitura é fundamental que se acompanhe o modo como João Cabral acaba expondo núcleos essenciais de sua poética ou de sua visão sobre a relação dialética entre signo e realidade. Cito aqui os dois textos que, em verdade, determinam hoje os meus propósitos para a aproximação de sua poética: "No Centenário de Mondrian" e "Exposição Franz Weissmann", ambos publicados em Museu de tudo (1977) e incluídos na referida Poesia crltica (1982). Com o olho e a mente voltados para a pintura e para a escultura, a palavra essencial do poeta nordestino resvala o inaudível e consegue engendrar os elementos mais profundos de uma poética; o que resta dessa poesia, no seu cinqüentenário, é uma espécie de "brinde" à navegação do silêncio incerto, plasmado no signo da criação.

\section{BIBLIOGRAFIA}

\section{SOBRE O AUTOR:}

MELO NETO, João Cabral de. Poesias completas. Rio de Janeiro, Jose Olympio, 1968.

- . Museu de tudo. Rio de Janeiro, José Olympio, 1976

- Escola das facas. Rio de Janeiro, José Olympio, 1980

- .Poesia crítica. Rio de Janeiro, José Olympio, 1982.

\section{OUTRAS OBRAS:}

CAMPOS, Augusto et alii. Mallarmé. São Paulo, Ed. Perspectiva, 1975.

DELEUZE, Gilles. Proust e os signos. Trad. port. Antonio Carlos Piquet e Roberto Machado. Rio de Janeiro, Forense Universitária, 1987.

ISER, Wolfgang. The act of reading. London, Routledge e Kegan Paul, 1978.

KRISTEVA, Julia. Introdução d semanálise. Trad. Lúcia Hena França Ferraz. São Paulo, Perspectiva, 1979. 